\title{
Human Resources Development and Migration: New Potential Determinants for Monetary Policy ${ }^{*}$
}

\author{
Gherghinescu Oana Rodica \\ University of Craiova, Craiova, Romania \\ Ciocîrlan Irina Georgiana \\ ACZ Consulting, Craiova, Romania
}

\begin{abstract}
The main objective of the present paper is to determine the potential impact the qualitative and quantitative tendencies in the labor market on the decisions which influence the design of monetary policy worldwide. The analysis is focused on how human resources and phenomena associated with them could influence potential growth and, further on, how they can impact monetary policy decisions at national level for European countries outside the euro area and at ECB level for the euro zone countries. Moreover, the paper will envisage potential macroeconomic reactions (monetary decisions herewith included) to human resources dynamics. The economic variations are regarded through the perspective of growth potential shown by the Research \& Development sector and also through the effects of labor force migration. The analysis of statistical data aims at pointing out the different economic perspectives in the European Union, the United States, and Japan, also considering the disparities between EU member states. The analysis is completed by the use of the ranking method, the conclusions stating once more the crucial importance of the human factor in drawing monetary policy decisions.
\end{abstract}

Keywords: human resources, migration, monetary policy, Research \& Development sector, economic growth, labour force, job creation

\section{Introductory Remarks}

Contemporary economics acknowledge more and more the need to correlate monetary policy design with the changing characteristics of the real economy.

Monetary policy determination, be it within a monetary or a direct inflation targeting regime, pays special attention to the trend growth of GDP as one of its essential determinants.

A component which is incorporated in the potential growth rate and has gained significant importance during the last decade in macroeconomic equations is the human factor. Labour markets in Europe are confronted

\footnotetext{
* Acknowledgment: This work was supported by the strategic grant POSDRU/89/1.5/S/61968, Project ID61968 (2009), co-financed by the European Social Fund within the Sectoral Operational Programme Human Resources Development 2007-2013.

Gherghinescu Oana Rodica, Ph.D. in Economics, Department of Economics and Business Administration, University of Craiova.

Ciocîrlan Irina Georgiana, MA in Economics, Department of EU funding, ACZ Consulting.

Correspondence concerning this article should be addressed to Gherghinescu Oana Rodica, Craiova, 33A Putnei Street, ap. 7, Craiova, Romania. E-mail: o_gherghinescu@yahoo.com.
} 
with prolonged shortages of skilled workers especially in the tertiary sector. Fewer and fewer qualified human resources enter the labour markets in public works, public services, and constructions as a consequence of inadequate education strategies in the field of vocational education and training. Another associated phenomenon is migration of labour force from Eastern to Western and Northern Europe, thus increasing the shortage of workers on the Eastern markets and putting inflationist pressure on the origin markets of workers via remittances.

In such a context, labor markets play an important indirect role in the design and conduct of monetary policy, highlighting the importance of labor as an important factor in the production functions of various economies. The present paper comprises four parts: the first one is dedicated to analyzing the rationale behind establishing a direct link between monetary policy and economic growth; the second part analyzes the role of human capital in the economic growth process in contemporary economies; the third part depicts and researches into four main challenges facing economic growth from the point of view of human resources, namely, lifelong learning, mobility, rigidities, and displacement; and the fourth part is dedicated to conclusions.

\section{Monetary Policy and Economic Growth}

Monetary policy is not an objective per se but a mechanism that is put in place in order to better serve the achievement of macro-economic objectives. Monetary policy objectives and instruments are designed in order to support general macroeconomic objectives, among which economic growth is essential. Empirical attempts have been made in order to establish a quantitative relationship between monetary policy and economic growth. In economic literature they have been categorized as either deterministic (the Taylor rule) or normative (quantitative benchmark definitions for money supply growth rate).

The Taylor rule provides recommendations on how the Federal Reserve should set the short-term interest rates in accordance with the economic conditions in order to achieve its short-run goal for stabilizing the economy and its long-run goal for inflation.

Starting October 1998, the Governing Council of the European Central Bank decided to announce a reference value for the growth rate of the broad monetary aggregate $\left(M_{3}\right)$ having as regressors the potential growth, the desired inflation rate (following the ECB's definition of price stability as an year-on-year increase in the HICP for the euro area of below 2\%) and the estimate of trends in the inverse of the velocity of circulation of money. A reference value for monetary growth of $4.5 \%$ per annum has been successively reconfirmed by the ECB, based on the assumptions regarding a trend for potential growth in the range of $2 \%-2.5 \%$ and a decline in $\mathrm{M}_{3}$ income velocity of $0.5 \%-1 \%$ per annum in the euro area.

This correlation mechanism does not, however, function automatically. There are several underlying factors for GDP growth rate, some of them radically changing during the last decades. One of the very dynamic factors is represented by human resources and their presence in the production function of a state under the categorization of labor.

\section{Human Capital and Economic Growth}

Human capital is without any doubt a key variable in the macro-economic equation of every state. Its quantity and quality exert impact on the level and trend of GDP growth together with other production factors. While quantity is affected by low birth prospects across most of the developed countries, quality of the human 
capital has gained importance through various initiatives such as investing more and more in education, as well as in research and development.

Education increases the mobility of the workforce within a labor market and is therefore essential for the functioning of a monetary union in which asymmetric economic shocks can no longer be absorbed by adapting the exchange rate relations but have to be offset by flexible factors of production (Liebscher et al., 2006). In its theory of optimum currency areas, Mundell (1961) has identified labor mobility as a strategic facet of an optimum currency area. His argument was that, when this production factor moves freely within the monetary area, adjustments to real shocks do not imply dramatic changes in the level of prices and income for member states. If, on the contrary, mobility is low, the monetary union is not desirable. Education does not only increase labor force mobility, but also its adaptability, productivity, and competitiveness, as key issues of Europe's revised Lisbon agenda. Although a time lag has been identified between the investment in education and its results in terms of increased competitiveness and economic growth, there is clear evidence that education and lifelong learning are an indispensable input for economic growth in the last decades.

Research and development (R\&D) should become a driving force behind economic growth, job creation, innovation of new products, and increasing quality of products.

A minimum set of six indicators can be used to assess the competitiveness potential of the EU economy in the spirit of the Lisbon Strategy for growth and jobs (see Tables 1-6 and Figures 1-6): (1) gross domestic expenditure on R\&D; (2) tertiary graduates in science and technology per 1,000 inhabitants aged 20-29 years; (3) the employment rate, calculated by dividing the number of persons aged 15 to 64 in employment by the total population of the same age group; (4) labor productivity per person employed; (5) research and development personnel, by sectors of performance; and (6) doctorate students in science and technology fields - total percent of the population aged 20-29.

The findings are as follows:

(1) Unless properly financed, R\&D is less likely to foster economic growth and job creation. If comparing the gross domestic expenditure on R\&D in the EU, USA, and Japan (see Table 1 and Figure 1), one can easily notice that further investements should be made in this direction in the EU in order to achieve the goals of the Lisbon Strategy.

Table 1

Gross Domestic Expenditure on R\&D, Percent of GDP

\begin{tabular}{|c|c|c|c|c|c|c|c|c|c|c|c|c|}
\hline & 2000 & 2001 & 2002 & 2003 & 2004 & 2005 & 2006 & 2007 & 2008 & 2009 & 2010 & 2011 \\
\hline EU-27* & 1.86 & 1.88 & 1.88 & 1.87 & 1.84 & 1.84 & 1.84 & 1.85 & 1.92 & 2.02 & 2.01 & 2.03 \\
\hline Euro area & 1.84 & 1.86 & 1.87 & 1.87 & 1.85 & 1.85 & 1.86 & 1.88 & 1.96 & 2.06 & 2.06 & 2.09 \\
\hline \multicolumn{13}{|l|}{ EU lowest percentage } \\
\hline (Romania) & 0.37 & 0.39 & 0.38 & 0.39 & 0.39 & 0.41 & 0.45 & 0.52 & 0.58 & 0.47 & 0.46 & 0.48 \\
\hline (Cyprus) & 0.25 & 0.26 & 0.3 & 0.35 & 0.37 & 0.41 & 0.43 & 0.44 & 0.43 & 0.49 & 0.5 & 0.48 \\
\hline EU highest percentage (Finland) & 3.34 & 3.30 & 3.36 & 3.43 & 3.46 & 3.48 & 3.45 & 3.47 & 3.7 & 3.94 & 3.9 & 3.78 \\
\hline United States & 2.73 & 2.74 & 2.64 & 2.67 & 2.67 & 2.58 & 2.61 & 2.69 & 2.82 & 2.87 & - & - \\
\hline Japan & 3.05 & 3.13 & 3.18 & 3.20 & 3.20 & 3.17 & 3.32 & 3.46 & 3.47 & 3.36 & - & - \\
\hline
\end{tabular}

(2) Table 2 shows data on tertiary science and technology graduates in the EU as an indicator of the science and technological potential of high-skilled graduates (see Figure 2). 
Table 2

Tertiary Graduates in Science and Technology Per 1,000 Inhabitants Aged 20-29 Years

\begin{tabular}{lrrrrrrrrrrr}
\hline & 2000 & 2001 & 2002 & 2003 & 2004 & 2005 & 2006 & 2007 & 2008 & 2009 & 2010 \\
\hline EU-27 $^{*}$ & 10.1 & 10.7 & 11.3 & 12.3 & 12.5 & 13.2 & 13.4 & 13.8 & 14.4 & 14.4 & 12.5 \\
EU lowest level (Cyprus) & 3.4 & 3.7 & 3.8 & 3.6 & 4.2 & 3.6 & 4.3 & 4.2 & 4.0 & 4.6 & 5.1 \\
EU highest level (Finland) & 16.0 & 17.2 & 17.4 & 17.4 & 17.9 & 18.1 & 17.9 & 18.8 & 24.3 & 19.0 & 24.2 \\
USA & 9.7 & 9.9 & 10.0 & 10.9 & 10.2 & 10.6 & 10.3 & 10.1 & 10.1 & 10.3 & 10.7 \\
Japan & 12.6 & 12.8 & 13.0 & 13.2 & 13.4 & 13.7 & 14.4 & 14.4 & 14.3 & 14.2 & 13.8 \\
\hline Notes. ${ }^{*}$ average calculated for the 27 Member & 27. States ( ${ }^{* *}$ as per January 1st, 2007); Source: Eurostat Statistics, 2012.
\end{tabular}

As it can be noticed, huge disparities persist between different countries in the EU, which brings on the top of the agenda the need to ensure homogenous priorities for higher education in the field of science and technology accross Europe. The European Union needs to train and use on the labor market as many high-skilled graduates as possible. This has been included among the priorities of the Bologna process and the financing priorities of the European Social Fund.

(3) In the spirit of the Lisbon strategy for growth and jobs, there can be established a correlation between the amounts of investments dedicated to R\&D and the employment rate (see Table 3 and Figure 3).

Table 3

Employment Rate in Percent

\begin{tabular}{|c|c|c|c|c|c|c|c|c|c|c|c|c|}
\hline & 2000 & 2001 & 2002 & 2003 & 2004 & 2005 & 2006 & 2007 & 2008 & 2009 & 2010 & 2011 \\
\hline EU-27* & 66.6 & 66.9 & 66.7 & 67.0 & 67.4 & 68.0 & 69.0 & 69.9 & 70.3 & 69.0 & 68.6 & 68.6 \\
\hline EU_-Changing composition & 67.3 & 67.9 & 68.1 & 68.4 & 68.9 & 68.3 & 69.2 & 69.9 & 70.3 & 69.0 & 68.6 & 68.6 \\
\hline EU lowest rate (Greece) & 61.9 & 61.5 & 62.5 & 63.6 & 64.0 & 64.6 & 65.7 & 66.0 & 66.5 & 65.8 & 64.0 & 59.9 \\
\hline EU highest rate (Sweden) & 77.7 & 78.7 & 78.5 & 77.9 & 77.4 & 78.1 & 78.8 & 80.1 & 80.4 & 78.3 & 78.7 & 80.0 \\
\hline United States & 76.9 & 76.1 & 75.0 & 74.5 & 74.5 & 74.8 & 75.3 & 75.3 & 74.5 & 71.3 & 70.5 & 70.4 \\
\hline Japan & 74.0 & 73.8 & 73.1 & 73.2 & 73.4 & 73.9 & 74.5 & 75.3 & 75.3 & 74.7 & 74.7 & 74.9 \\
\hline
\end{tabular}

(4) Both the level of expenditure on R\&D and the level of investments in education are to be reflected in the productivity per person employed (see Table 4 and Figure 4).

Table 4

Labor Productivity Per Person Employed EU $27=100$

\begin{tabular}{|c|c|c|c|c|c|c|c|c|c|c|c|c|}
\hline & 2000 & 2001 & 2002 & 2003 & 2004 & 2005 & 2006 & 2007 & 2008 & 2009 & 2010 & 2011 \\
\hline$\overline{E U-27^{*}}$ & 100.0 & 100.0 & 100.0 & 100.0 & 100.0 & 100.0 & 100.0 & 100.0 & 100.0 & 100.0 & 100.0 & 100.0 \\
\hline EU—Changing composition & 113.9 & 112.6 & 111.8 & 111.0 & 109.9 & 109.9 & 109.8 & 109.6 & 109.7 & 109.2 & 108.7 & 108.5 \\
\hline EU lowest rate (Bulgaria) & 31.3 & 32.2 & 34.0 & 34.8 & 34.8 & 35.8 & 36.4 & 37.5 & 39.6 & 40.1 & 41.3 & 43.5 \\
\hline $\begin{array}{l}\text { EU highest rates } \\
\text { (Luxembourg) } \\
\text { (Belgium) }\end{array}$ & $\begin{array}{l}176.8 \\
137.3\end{array}$ & $\begin{array}{l}163.1 \\
134.2\end{array}$ & $\begin{array}{l}164.2 \\
137.1\end{array}$ & $\begin{array}{l}168.2 \\
135.6\end{array}$ & $\begin{array}{l}170.6 \\
132.6\end{array}$ & $\begin{array}{l}170.3 \\
130.5\end{array}$ & $\begin{array}{l}179.5 \\
129.3\end{array}$ & $\begin{array}{l}180.0 \\
127.7\end{array}$ & $\begin{array}{l}168.6 \\
127.1\end{array}$ & $\begin{array}{l}161.6 \\
127.8\end{array}$ & $\begin{array}{l}167.9 \\
128.3\end{array}$ & $\begin{array}{l}169.8 \\
127.4\end{array}$ \\
\hline United States & 142.5 & 140.9 & 140.9 & 142.6 & 143.5 & 144.4 & 140.6 & 139.4 & 138.1 & 140.9 & 142.9 & 143.5 \\
\hline Japan & 100.6 & 99.6 & 100.1 & 100.8 & 100.9 & 100.3 & 97.5 & 97.5 & 95.3 & 92.9 & 96.4 & 95.1 \\
\hline
\end{tabular}

Notes. " average calculated for the 27 Member ${ }^{* * *}$ States ( ${ }^{* * *}$ as per January 1st, 2007); Source: Eurostat Statistics, 2012.

(5) The information regarding the percentage of personnel currently working in the Research \& Development sector can be viewed below (see Table 5 and Figure 5). 
Table 5

Research and Development Personnel, by Sectors of Performance, Head Count (Percent of the Labour Force)

\begin{tabular}{lllllllllllll}
\hline & 2000 & 2001 & 2002 & 2003 & 2004 & 2005 & 2006 & 2007 & 2008 & 2009 & 2010 & 2011 \\
\hline EU-27 & 0.90 & 0.91 & 0.92 & 0.93 & 0.93 & 0.95 & 0.98 & 1.00 & 1.03 & 1.04 & 1.05 & 1.08 \\
Euro Area & 1.00 & 1.00 & 1.01 & 1.00 & 1.01 & 1.02 & 1.05 & 1.08 & 1.12 & 1.14 & 1.16 & 1.17 \\
EU lowest rate (Romania) & 0.30 & 0.29 & 0.32 & 0.34 & 0.34 & 0.34 & 0.29 & 0.29 & 0.31 & 0.29 & 0.36 & 0.30 \\
EU highest rates & & & & & & & & & & & & \\
(Luxembourg) & 1.97 & - & - & 2.06 & 2.18 & 2.16 & 2.14 & 2.18 & 2.18 & 2.06 & 2.16 & 2.11 \\
(Denmark) & 1.33 & 1.39 & 1.49 & 1.45 & 1.47 & 1.50 & 1.54 & 1.61 & 1.98 & 1.90 & 1.96 & 1.96 \\
Japan & 1.33 & 1.29 & 1.25 & 1.29 & 1.31 & 1.35 & 1.37 & 1.37 & 1.33 & 1.33 & - & - \\
\hline
\end{tabular}

Notes. " average calculated for the 27 Member ${ }^{* * *}$ States (" as per January 1st, 2007); Source: Eurostat Statistics, 2012.

(6) The level of interest regarding the Research \& Development sector amongst graduate students who wish to pursue a career in this innovative domain, is reflected in the following table (see Table 6 and Figure 6).

Table 6

Doctorate Students in Science and Technology Fields-Total \% of the Population Aged 20-29

\begin{tabular}{lllllllllllll}
\hline & 2000 & 2001 & 2002 & 2003 & 2004 & 2005 & 2006 & 2007 & 2008 & 2009 & 2010 & 2011 \\
\hline EU-27 & - & - & - & - & - & - & 0.27 & 0.30 & - & - & - & - \\
EU lowest rates & & & & & & & & & & & & \\
(Bulgaria) & 0.11 & 0.13 & 0.14 & 0.16 & 0.19 & 0.20 & 0.22 & 0.22 & 0.19 & 0.16 & 0.16 & - \\
(Hungary) & 0.10 & 0.15 & 0.01 & 0.48 & 0.17 & 0.17 & 0.18 & 0.16 & 0.16 & 0.16 & 0.17 & \\
EU highest rates & & & & & & & & & & & & \\
(Finland) & 1.30 & 1.34 & 1.33 & 1.23 & 1.32 & 1.33 & 1.36 & 1.38 & 1.36 & 1.30 & 1.29 & - \\
(Czech Republic) & 0.45 & 0.55 & 0.59 & 0.67 & 0.73 & 0.79 & 0.68 & 0.72 & 0.81 & 0.81 & 0.84 & \\
\hline
\end{tabular}

Notes. $^{*}$ average calculated for the 27 Member ${ }^{* * *}$ States ( ${ }^{* * *}$ as per January 1st, 2007); Source: Eurostat Statistics, 2012.

The connection between schooling and economic growth and between education and the development of financial markets has been also explored (Papademos, 2007). It has been pointed out that private returns on investment in education ranged between roughly $6.5 \%$ and $9 \%$ and that social returns were possibly even higher due to positive externalities. An additional year of formal schooling is associated with an increase in wages of $7.5 \%$ on average over the entire working life. Education can also influence growth via innovation. Higher education levels foster innovation and the adoption of technological advances. Particularly the most technologically advanced countries benefit from better education, which fuels growth in new sectors such as pharmaceuticals and electronics.

Based on the analyses through the usage of the ranking method (see Table 7), it is concluded that, considering the range of the appointed indicators, the most competitive country/Union in the Reaserch \& Development sector is the United States of America, followed by Japan and the European Union. The differences between the three subjects of the analyses through the ranking method are not overwhelming, which can be a sign of a possible change in the hierarchy, especially considering the emphasis on R\&D in the European Union's 2020 Strategy.

Applying the same ranking method but to different subjects (see Table 8), the analyses being focused this time on the countries which have become part of the European Union since 2004, the most competitive latest member of the European Union in the Research \& Development sector is the Czech Republic, followed closely by Slovenia. Between the first five scorings obtained, the difference is progressive, followed by a significant gap between the ocuupant of the 5th spot, Lithuania, and the occupant of the 6th spot, Poland. As it was expected, the last two countries which have been integrated in the EU in 2007, Romania and Bulgaria, have yet to become competitive in the Research \& Development sector. 


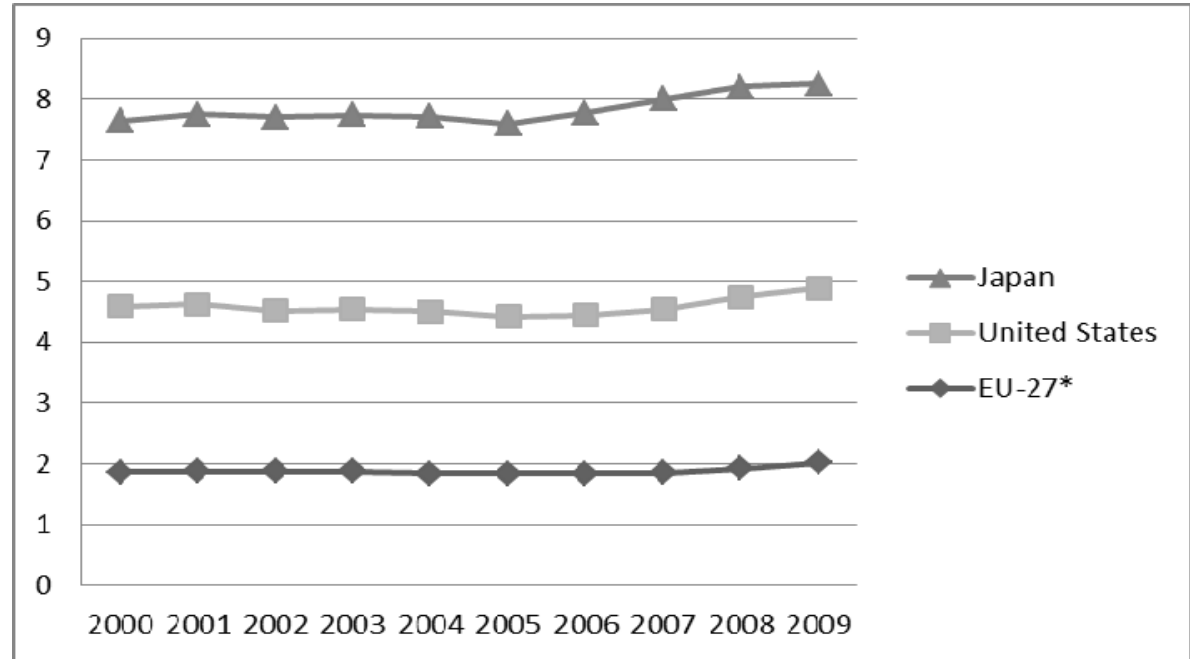

Figure 1. Gross domestic expenditure on R\&D, \% of GDP.

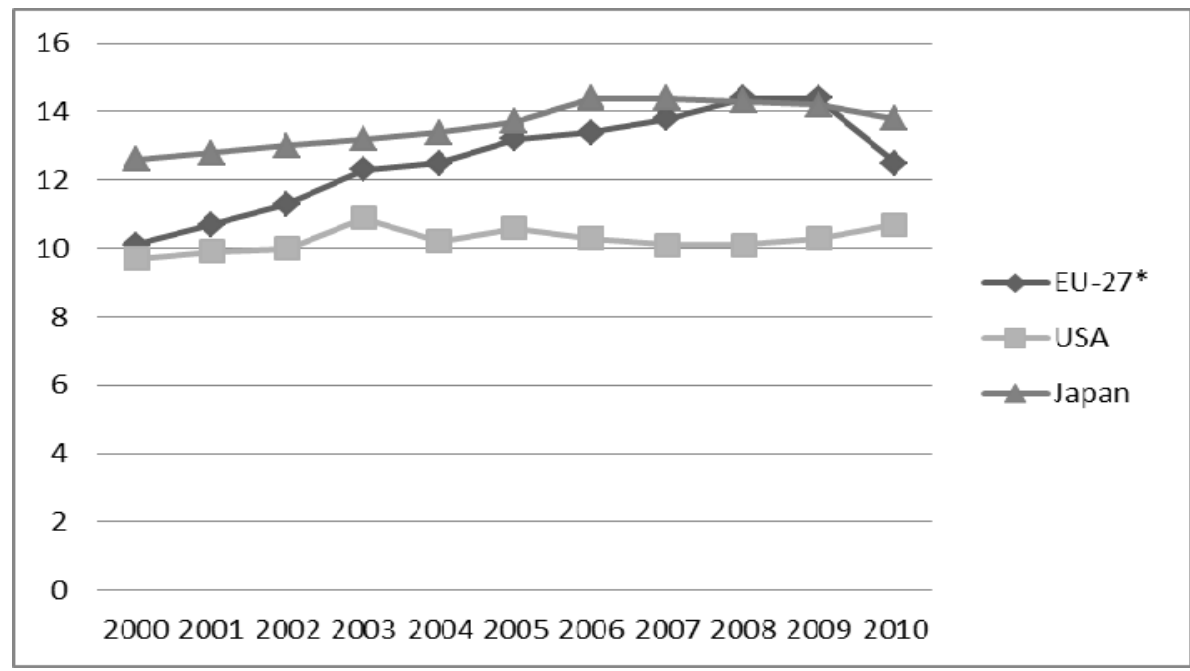

Figure 2. Tertiary graduates in science and technology per 1,000 inhabitants aged 20-29 years.

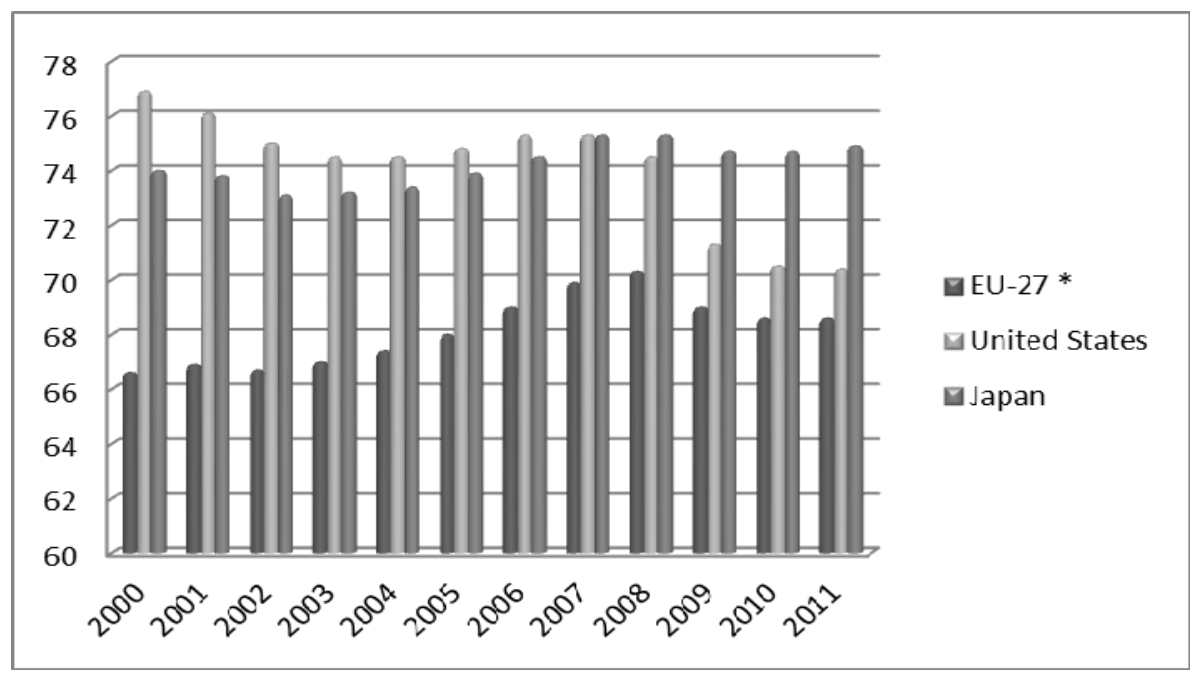

Figure 3. Employment rate in \%. 


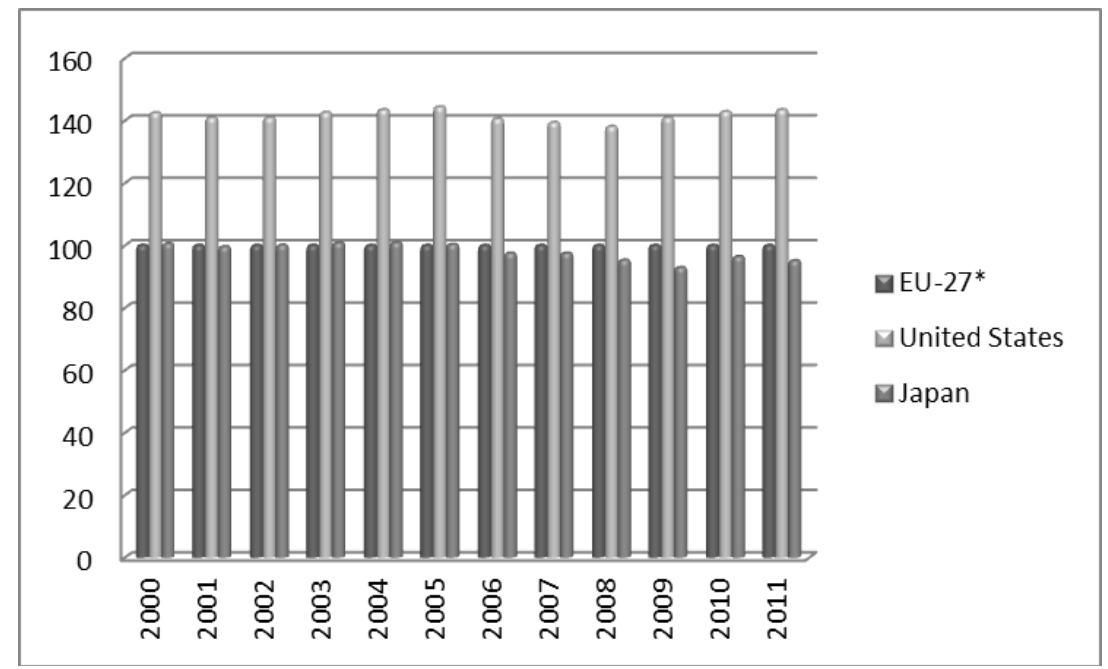

Figure 4. Labor productivity per person employed, EU $27=100$.

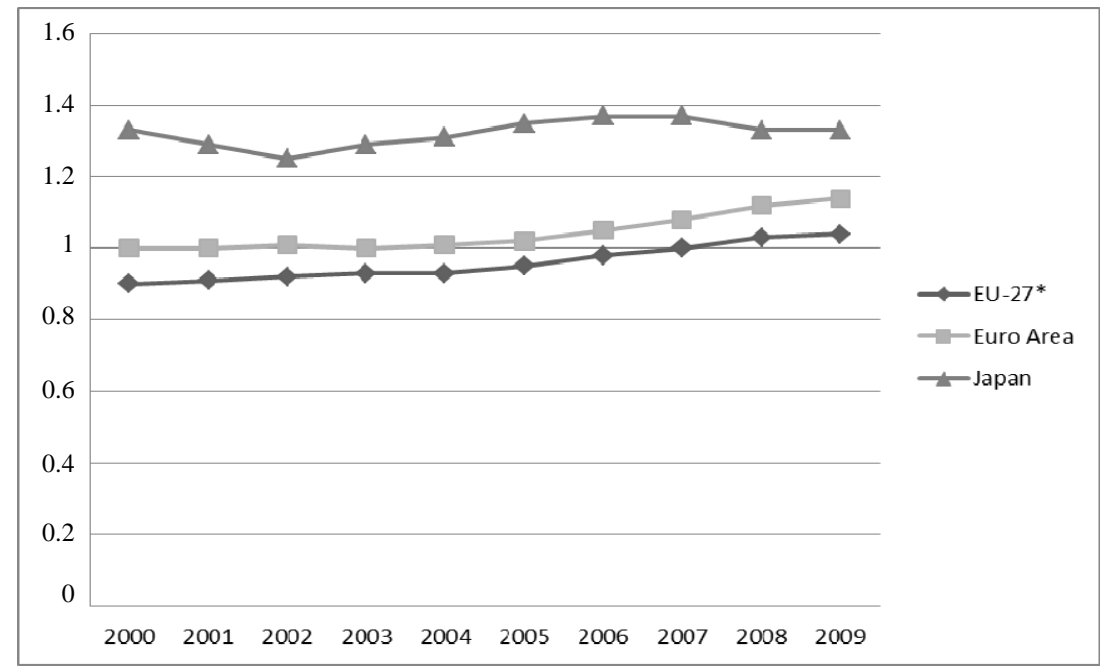

Figure 5. Research and development personnel, by sectors of performance (\% of the labour force).

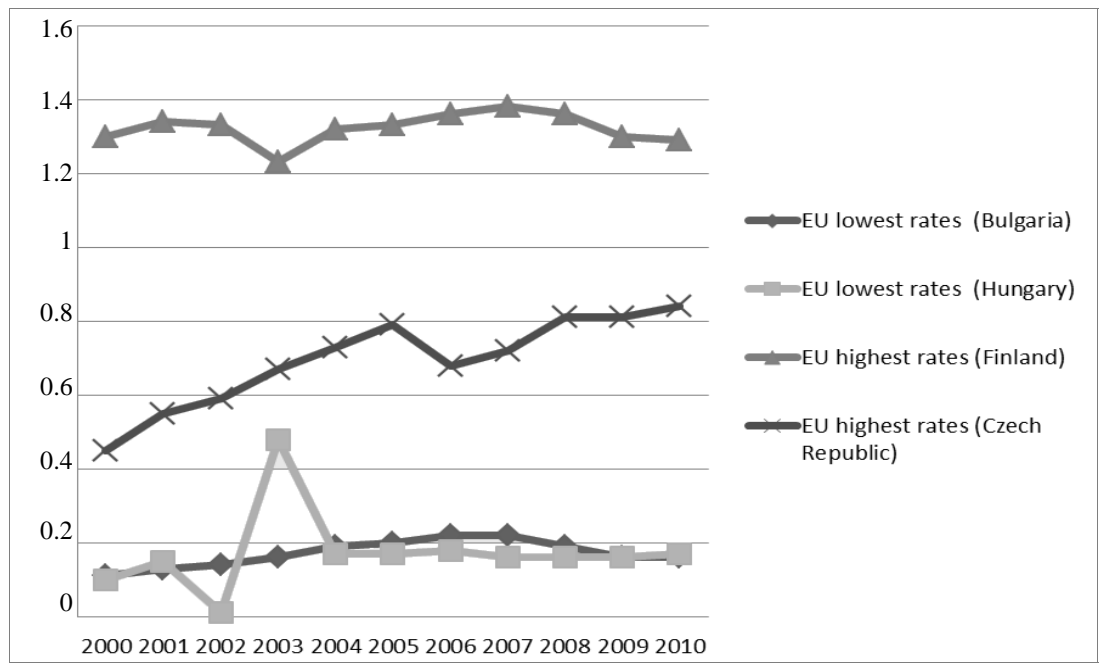

Figure 6. Doctorate students in science and technology fields-Total percent of the population aged 20-29. 
Table 7

Ranking Method-Indicators Regarding the R\&D Sector Analysed for the EU, USA, and Japan

\begin{tabular}{|c|c|c|c|c|c|c|c|c|c|c|c|}
\hline \multirow[b]{2}{*}{$\begin{array}{l}\text { Country/ } \\
\text { Union }\end{array}$} & \multicolumn{4}{|c|}{ Indicators-year 2009} & \multicolumn{7}{|c|}{ Ranking method } \\
\hline & $\begin{array}{l}\text { Gross } \\
\text { domestic } \\
\text { expenditure } \\
\text { on R\&D, \% } \\
\text { of GDP }\end{array}$ & $\begin{array}{l}\text { Tertiary } \\
\text { graduates } \\
\text { in science } \\
\text { and } \\
\text { technology } \\
\text { per 1,000 } \\
\text { inhabitants } \\
\text { aged 20-29 } \\
\text { years }\end{array}$ & $\begin{array}{l}\text { Employment } \\
\text { rate in \% }\end{array}$ & $\begin{array}{l}\text { Labor } \\
\text { productivity } \\
\text { per person } \\
\text { employed } \\
\text { EU } 27= \\
100\end{array}$ & $\begin{array}{l}\text { Gross } \\
\text { domestic } \\
\text { expenditure } \\
\text { on R\&D, \% } \\
\text { of GDP }\end{array}$ & $\begin{array}{l}\text { Tertiary } \\
\text { graduates } \\
\text { in science } \\
\text { and } \\
\text { technology } \\
\text { per 1,000 } \\
\text { inhabitants } \\
\text { aged 20-29 } \\
\text { years }\end{array}$ & $\begin{array}{l}\text { Employment } \\
\text { rate in \% }\end{array}$ & $\begin{array}{l}\text { Labor } \\
\text { productivity } \\
\text { per person } \\
\text { employed } \\
\text { EU } 27= \\
100\end{array}$ & $\begin{array}{l}\text { Cumulated } \\
\text { ranks }\end{array}$ & $\begin{array}{l}\text { Intermediary } \\
\text { rank }\end{array}$ & $\begin{array}{l}\text { Final } \\
\text { rank }\end{array}$ \\
\hline EU-27 & 2.02 & 14.4 & 69.0 & 100 & 3 & 1 & 3 & 2 & 9 & 2.25 & 3 \\
\hline USA & 2.87 & 10.3 & 71.3 & 140.9 & 1 & 3 & 2 & 1 & 7 & 1.75 & 1 \\
\hline Japan & 2.36 & 14.2 & 74.7 & 92.9 & 2 & 2 & 1 & 3 & 8 & 2 & 2 \\
\hline
\end{tabular}

Note. Source: Eurostat, 2012.

Table 8

Ranking Method-Indicators Regarding the R\&D Sector Analysed for the Latest 12 Member States of the EU

\begin{tabular}{|c|c|c|c|c|c|c|c|c|c|c|c|c|c|c|c|}
\hline \multirow[b]{2}{*}{$\begin{array}{l}\text { EU } \\
\text { Country }\end{array}$} & \multicolumn{6}{|c|}{ Indicators - year 2010} & \multicolumn{9}{|c|}{ Ranking method } \\
\hline & $\begin{array}{l}\text { Gross } \\
\text { domestic } \\
\text { expenditure } \\
\text { on R\&D, \% } \\
\text { of GDP }\end{array}$ & $\begin{array}{l}\text { Tertiary } \\
\text { graduates } \\
\text { in S\&T per } \\
1,000 \\
\text { inhabitants } \\
\text { aged } 20-29 \\
\text { years }\end{array}$ & $\begin{array}{l}\text { Employment } \\
\text { rate in \% }\end{array}$ & $\begin{array}{l}\text { Labor } \\
\text { productivity } \\
\text { per person } \\
\text { employed } \\
\text { EU } 27=100\end{array}$ & $\begin{array}{l}\text { R\&D } \\
\text { personnel, by } \\
\text { sectors of } \\
\text { performance } \\
\text { Head count (\% } \\
\text { of the labour } \\
\text { force) }\end{array}$ & $\begin{array}{l}\text { Doctorate } \\
\text { students in } \\
\text { S\&T fields } \\
\text {-Total } \\
\% \text { of the } \\
\text { population } \\
\text { aged } 20-29\end{array}$ & $\begin{array}{l}\text { Gross } \\
\text { domestic } \\
\text { expenditure } \\
\text { on R\&D, \% } \\
\text { of GDP }\end{array}$ & $\begin{array}{l}\text { Tertiary } \\
\text { graduates in } \\
\text { S\&T per } \\
1,000 \\
\text { inhabitants } \\
\text { aged 20-29 } \\
\text { years }\end{array}$ & $\begin{array}{l}\text { Employment } \\
\text { rate in \% }\end{array}$ & $\begin{array}{l}\text { Labor } \\
\text { productivity } \\
\text { per person } \\
\text { employed } \\
\text { EU } 27=100\end{array}$ & $\begin{array}{l}\text { R\&D } \\
\text { personnel, } \\
\text { by sectors of } \\
\text { performance } \\
\text { Head count } \\
\text { (\% of the } \\
\text { labour force) }\end{array}$ & $\begin{array}{l}\text { Doctorate } \\
\text { students in } \\
\text { S\&T } \\
\text { fields- } \\
\text { Total } \\
\% \text { of the } \\
\text { population } \\
\text { aged } 20-29\end{array}$ & $\begin{array}{l}\text { Cumulated } \\
\text { ranks }\end{array}$ & $\begin{array}{l}\text { Intermediary } \\
\text { rank }\end{array}$ & $\begin{array}{l}\text { Final } \\
\text { rank }\end{array}$ \\
\hline Romania & 0.48 & 15.6 & 63.3 & 48.9 & 0.26 & 0.31 & 12 & 5 & 10 & 11 & 12 & 5 & 55 & 9.17 & 12 \\
\hline Bulgaria & 0.57 & 11.4 & 65.4 & 41.3 & 0.49 & 0.16 & 10 & 7 & 5 & 12 & 8 & 11 & 53 & 8.83 & 11 \\
\hline Cyprus & 0.48 & 5.1 & 75.4 & 90.7 & 0.32 & 0.20 & 12 & 12 & 1 & 2 & 11 & 7 & 45 & 7.50 & 7 \\
\hline $\begin{array}{l}\text { Czech } \\
\text { Republic }\end{array}$ & 1.84 & 16.5 & 70.4 & 73.8 & 0.99 & 0.84 & 3 & 3 & 2 & 5 & 2 & 1 & 16 & 2.67 & 1 \\
\hline Estonia & 2.38 & 11.3 & 66.7 & 69.3 & 0.77 & 0.56 & 2 & 8 & 4 & 7 & 3 & 2 & 26 & 4.33 & 3 \\
\hline Hungary & 1.21 & 8.3 & 60.4 & 70.1 & 0.74 & 0.17 & 4 & 10 & 11 & 6 & 5 & 10 & 46 & 7.67 & 8 \\
\hline Latvia & 0.70 & 10.7 & 65.0 & 54.8 & 0.49 & 0.19 & 8 & 9 & 6 & 10 & 8 & 8 & 49 & 8.17 & 9 \\
\hline Lithuania & 0.92 & 18.7 & 64.4 & 62.5 & 0.75 & 0.23 & 5 & 1 & 9 & 9 & 4 & 6 & 34 & 5.67 & 5 \\
\hline Malta & 0.73 & 8.0 & 60.1 & 93.7 & 0.64 & 0.03 & 7 & 11 & 12 & 1 & 7 & 12 & 50 & 8.33 & 10 \\
\hline Poland & 0.77 & 15.8 & 64.6 & 66.8 & 0.46 & 0.19 & 6 & 4 & 7 & 8 & 10 & 8 & 43 & 7.17 & 6 \\
\hline Slovakia & 0.68 & 18.3 & 64.6 & 81.5 & 0.67 & 0.50 & 9 & 2 & 7 & 3 & 6 & 3 & 30 & 5.00 & 4 \\
\hline Slovenia & 2.47 & 14.8 & 70.3 & 80.5 & 1.24 & 0.43 & 1 & 6 & 3 & 4 & 1 & 4 & 19 & 3.17 & 2 \\
\hline
\end{tabular}

Note. Source: Eurostat, 2012.

\section{Challenges Ahead}

Monetary authorities become more and more aware of the importance of labor as a variable in the macroeconomic equations. This is particularly supported by certain recent phenomena such as: migration and remittances; rigidity of labor and wages in certain markets and the rising importance of services and associated labor in the production function.

\section{Migration and Remittances}

A relatively new phenomenon in the European Union is represented by the migration of low-skilled labor force from Eastern to Western countries and the subsequent remittances for their family members left in the origin countries. According to World Bank data, remittances at global level amounted for over 230 billion dollars 
in 2004. For numerous European and Central Asia countries, remittances represent a second source of external financing after foreign direct investments or could even be the main source of external financing as is the case of Moldova and Albania. In low income countries, remittances represent approximately 20\% of household expenses. Moreover, in countries like Moldova, Serbia, and Montenegro, remittances account for half of total export inflows, while in Albania and Bosnia-Herzegovina, they are almost equal to exports.

This type of phenomenon, if properly managed, can prove beneficial for both the origin and the destination country of migrant labor. For the destination country it is a source of labor needed in the production function of the economy, especially in sectors such as services, constructions, and agriculture as well as a dynamic factor for the economy. For the origin country of migrant labor and, consequently, the destination country of remittances, this is a poverty reduction factor. This inflow of foreign currency supports economic growth and helps increasing the living standard, smoothing social tensions. Various econometric models show contradictory results as regards the impact of remittances on economic growth. Chami, Fullenkamp, and Jahjah (2003) conclude that, because of asymmetries and uncertainties, remittances have, at the end of the day, a negative impact on the economic growth in their countries of destination. However, using a similar model with slight changes and additional institutional variables, Mansoor and Quillin (2006) show that remittances stimulate economic growth. Irrespective of these contradictions, there are issues that have general validity, namely: (1) the scope and rhythm of remittances decrease in time as families tend to gather either in the origin or in the destination country; (2) remittances improve the balance of payments of the country where migrant labor originates; and (3) while active, labor migration tends to have negative social consequences such as breaks in families unity and poor performance of children left at home by their parents as well as stagnation in the communities deprived by a large share of their active labor force.

A very debated effect of remittances flows is the one related to the appreciation of the real exchange rate and the connected macroeconomic effects, such as: adverse effects on the tradable sector of the economy affected by the associated loss of international competitiveness; reductions in the labor supply of the tradable sector in favour of the non-tradable sector, wage pressure, and price increase in the non-tradable sector; widening the current account deficit when consumption driven by remittances is also directed towards tradable goods, thus increasing the demand for imports; inflationary pressures when remittances flows do not leave the country and inflate monetary aggregates; distortions in the sectoral allocation of investments, given the fact that most of the remittances flows are directed towards the real estate market, thus artificially inflating the price of assets.

\section{Rigidity of Labor and Wages in Certain Markets}

A recent study carried out by the European Central Bank (Christoffel, Kuster, \& Linzert, 2006) highlights the role of labor markets for understanding business cycle fluctuations and the implications for monetary policy in particular. The focus of the analyses is linked to the approach of rigid labor markets when conducting monetary policy based on regimes such as inflation targeting. Rigid labor market regimes can influence monetary policy transmission mechanism according to an algorithm similar to the following one: nominal wage rigidity, the speed of mobilizing idle labor resources and the cost of mobilizing them all influence the marginal cost of labor; this will be transposed in firms' marginal cost as part of their price setting mechanism and finally feed aggregate inflation. Hence, it can be stated that wage inertia level and the efficiency of labor demand-supply matching 
process have a strong impact on monetary policy transmission mechanism. This is the reason for which the labor market and wage flexibility have been considered key pre-requisites for an optimum currency area. The higher the degree of wage rigidity, the stronger inflation persistence can be. In such a context, optimal policy should deviate from the strict regime of inflation targeting and fully acknowledge the unemployment/inflation trade-off. Thus optimal monetary policy should envisage a mix of inflation targeting and unemployment targeting.

\section{Changes in the Production Function}

If trend growth of GDP is a key ingredient for monetary policy determination, then volatility and determination of trend growth must be understood as well as possible. Against this background it is worrying that recently volatility of potential growth seems to have increased and its determination seems to have shifted, whereas it is at first sight puzzling why and in which direction. Potential growth is the trend growth of the economy. Actual growth is regarded as the result of this structural growth and the deviation from it due to the business cycle stance. Insight in the level of structural or potential growth of the economy is important, e.g., for monetary policy and to assess the employment situation. This is the more the case because short term economic developments seem to have also become more volatile, less policy driven, and more difficult to explain (Kolodziejak \& Gherghinescu, 2005).

The trend is caused by underlying factors, which are the determinants of economic growth. These factors are endowments or production inputs on the one hand and their respective productivity on the other hand. In the history of economic thought it can be observed that the interest moves from the first sector of the economy, agriculture, to the second, industry, in the course of the 19th century which also marks the birth of economics as a science. Following the traditional concept of economic growth determination a capital stock that has been built will always result in production as long as labour costs are in accordance with the competitive position or technological position of that capital stock. However, with the preferences of the consumers drifted to the output of the third and fourth sector of the economy, to commercial and non-commercial services, it is doubtful whether a capital centred approach to potential growth determination is adequate. This is sometimes solved by the introduction of human capital in the production function. What it is noticed nowadays is that the production function of the economy changes in response to preference drifts, sectoral changes, and consumption changes. Immigration/inflow of labor can trigger changes in the economic preferences for services that were previously desired, e.g., because of aging, but not possible. Nowadays the service sector plays a major role in our economy. In response to aging preference dynamics towards services may continue and deepen. Such an approach shows that changes in the production function of the economy (i.e., shifts from the capital intensive sector-industry to the labor intensive sector-services) are able to support economic growth even in economies characterized by low accumulation, relatively low savings, and a relatively low capital output ratio (the case of USA or Canada). This is in line with the Rybczynski (1955), a core result of Heckscher-Ohlin trade theory, stating that when a region is open to trade with other regions, changes in regional relative factor supplies can be fully accommodated by changes in regional output without requiring changes in regional factor prices.

\section{Conclusions}

Although historically ignored as significant variable for monetary policy decisions, human resources, under their various facets, can play a crucial part in the formulation and transmission of monetary policy and are 
definitely crucial for supporting economic growth.

Several conclusions have been depicted from the present paper as regards the relevance of incorporating human resources and labor dynamics in macroeconomic analyses and, in particular, in monetary analyses.

(1) Labor is an important factor in the production function of many economies. Moreover, labor dynamics among countries can initiate changes in the preference dynamics for certain sectors (i.e., services) that had not been able to be satisfied before. This explains how economies with low accumulation, relatively low savings and a relatively low capital output ratio, but open to immigration flows have been able to efficiently integrate this labor into the services sector and gain economic growth.

(2) Although quantity of labor is affected by low birth prospects across most of the developed countries, quality of the human capital has gained importance through various initiatives such as investing more and more in education, as well as in research and development. It has been statistically demonstrated (even though with a time lag) that investments in human resources support economic growth and encourage mobility and flexibility in the labor market as prerequisites for the functioning of optimum monetary areas.

(3) Effects of the remittances flows can not be neglected while formulating monetary and exchange rate policies in the recipient countries as they are likely to feed real exchange rate appreciation, inflation, and distortions in certain markets.

(4) Wage inertia level and the efficiency of labor demand-supply matching process have a strong impact on monetary policy transmission mechanism. In rigid labor markets, an optimal monetary policy based on inflation targeting should not neglect unemployment targeting.

\section{References}

Chami, R., Fullenkamp, C., \& Jahjah, S. (2003). Are immigrant remittance flows a source of capital for development? Palgrave Macmillan, 52(1), 55-81.

Christoffel, K., Kuster, K., \& Linzert, T. (2006). Identifying the role of labor markets for monetary policy in an estimated DSGE model. ECB Working Paper Series, No. 635.

European Commission. (2005). New proposals for growth and jobs under the next Financial Framework 2007-13. Retrieved from http://www.europa.eu

Eurostat Statistics. (2012). Retrieved from http://www.epp.eurostat.ec.europa.eu/portal/page/portal/statistics/themes

Faia, E. (2006). Optimal monetary policy rules with labor market frictions. ECB Discussion Paper No. 698.

Janger, J., \& Raunig, B. (2007). Human capital and economic growth-Summary of the 35th Economics Conference of the Oesterreichische Nationalbank (pp. 106-114). Monetary Policy and the Economy No. 3.

Kolodziejak, A., \& Gherghinescu, O. (2005). Preference dynamics, migration and potential growth: Implications for monetary policy. Finance-Challenges of the Future Review, No. 3.

Liebscher, K., Christl, J., Peter Mooslechner, P., \& Ritzberger-Grünwald, D. (2006). Financial development, integration and stability (pp. 186-207). USA: Edward Elgar Publishing.

Mansoor, A., \& Quillin, B. (2006). Migration and remittances: Eastern Europe and the Former Soviet Union (Europe and Central Asia Reports). Washington: World Bank Publications.

Mundell, R. (1961). A theory of optimum currency areas. The American Economic Review, 51(4), 657-665.

Papademos, L. (2007). Inflation and competitiveness divergences in the Euro area countries: Causes, consequences and policy responses. Proceedings from The ECB and its Watchers IX, ECB Press.

Rybczynski, T. M. (1955). Factor endowment and relative commodity prices. Economica, 22(88), 336-341. 